\title{
経過不良歯科用インプラントの臨床的検討
}

\author{
加藤仁夫・松田詠子・武田譲 \\ 湊 耕一山山口福光・中野裕理* \\ 石井達郎*·追川哲雄・泉廣次
}

\section{A clinical study of unsuccessful dental implants}

\author{
Takao Kato $\cdot$ Utako Matsuda $\cdot$ Yuzuru Takeda \\ Koichi Minato $\cdot$ Fukumitsu Yamaguchi $\cdot$ Yuri NaKano* \\ Tatsuo IshiI* ${ }^{*}$ Tetsuo OiKawa $\cdot$ Hirotsugu IzUmI
}

\begin{abstract}
We analyzed clinically 36 patients in whom dental implants were unsuccessful. The patients presented for implants treatment at the Department of Oral Surgery, Nihon University School of Dentistry at Matsudo from January 1989 through December 1993.

The results were as follows:

1. The male: female ratio of the patients was $1: 1$ and the largest age group was from 40 to 69 years.

2. Type of implant: endosteal implant (31 cases), subperiosteal implant ( 3 cases), endodontic implant ( 1 case), endosteal implant and endodontic implant concurrently ( 1 case).

3. Chief complaint: excessive implant mobility ( 8 cases), gingival swelling ( 7 cases), occlusal pain ( 6 cases), spontaneous pain ( 5 cases).

4. Present condition: excessive implant mobility (23 cases), resorption of alveolar bone (17 cases), pus discharge (12 cases), swelling ( 9 cases), spontaneous pain ( 9 cases), occlusal pain ( 7 cases), bleeding ( 4 cases), paralysis ( 4 cases).

5 . Secondary conditions: alveolar ostitis (28 cases), maxillary sinusitis ( 5 cases), ostitis of the jaw ( 3 cases), temporomandibular arthrosis ( 3 cases), paralysis of the inferior alveolar nerve ( 3 cases).

6 . Some symptoms developed in 15 patients from immediately after implant operation. In spite of discomfort, implants were used for an average of 5.1 years.
\end{abstract}

Key words: dental implant (歯科インプラント), clinical study (臨床的検討), unsuccessful implant （経過不良インプラント）

日本大学松戸歯学部第 1 口腔外科学教室

(主任 : 追川哲雄教授)

*日本大学松戸歯学部第 2 口腔外科学教室 (主任 : 中村武夫教授)

First Department of Oral Surgery, Nihon University School of Dentistry at Matsudo (Chief: Prof.
Tetsuo Oikawa)

*Second Department of Oral Surgery, Nihon University School of Dentistry at Matsudo (Chief: Prof. Takeo Nakamura)

受付日: 平成 6 年 9 月 26 日 
緒 言

デンタルインプラント（以下インプラント）は材質 および術式などの進歩とともに臨床例も年を追うごと に増加してきた ${ }^{1)}$.しかし，なかには継発症のために インプラントを除去しなければならない症例もある。 インプラントの継発症についての報告はいくつかみら れるが2 18)，いずれも症例数が少なく一定の傾向を 把握し難い，そこで，われわれは当院に来院した経過不 良インプラント 36 例について検討を行ない, 経過不良
症例の実態に関して若干の知見を得たので報告する.

\section{対象および検討方法}

対 象： 1989 年 1 月から 1993 年 12 月までの 5 年間 に本学部付属歯科病院に来院したインプラント経過不 良症例のうち, 何らかの処置を施した 36 症例を対象 とした。

検討方法 : 検討は独自のプロトコールに基づいて, (1)性別・年齢分布, (2)来院経路, (3)インプラント装着

表 1 症例

\begin{tabular}{|c|c|c|c|c|c|c|c|c|c|c|c|c|}
\hline 症例 & 年齢 & 性別 & 来院経路 & 装置数 & 修復部位 & 形式 & 形態 & 材質 & 主訴 & 継発症 & 基礎疾患 & 衛生状態 \\
\hline 1 & 36 & 女 & 埋入歯科 & 1 & 下臼歯 & 骨内 & $\mathrm{S}$ & $\mathrm{B}$ & 神経麻疽 & 下歯槽神経麻㾝 & なし & 普 \\
\hline 2 & 51 & 女 & 他歯科 & 2 & 上下前臼 & 骨内 & $\mathrm{S}$ & $\mathrm{P}$ & 動摇 & 歯槽骨炎·神経麻瘒 & なし & 普 \\
\hline 3 & 57 & 男 & 他歯科 & 1 & 下臼柬 & 骨内歯内 & $\mathrm{BP}$ & $\mathrm{B}$ & 排膿 & 歯槽骨炎 & 糖尿高血圧腎 & 悪 \\
\hline 4 & 70 & 男 & 他歯科 & 1 & 上臼歯 & 骨内 & $\mathrm{B}$ & $\mathrm{B}$ & 咬合痛 & 歯槽骨炎 & 筫血 & 悪 \\
\hline 5 & 46 & 男 & 他歯科 & 1 & 上兒歯 & 骨膜下 & 0 & - & 排膿 & 上顎洞炎 ·顎関節症 & なし & 良 \\
\hline 6 & 46 & 女 & 紹介無 & 1 & 下臼歯 & 骨内 & $\mathrm{B}$ & $\mathrm{B}$ & 神経麻㾇 & 下歯槽神経麻䡒 & 貧血 & 普 \\
\hline 7 & 49 & 男 & 他歯科 & 1 & 上前臼歯 & 骨内 & $\mathrm{S}$ & $\mathrm{BP}$ & 腫脹 & 歯槽骨炎 & 高血圧 & 普 \\
\hline 8 & 50 & 男 & 他歯科 & 1 & 上前歯 & 骨内 & $\mathrm{B}$ & B & 咬合痛 & 歯槽骨炎 & 腎, 高血圧 & 悪 \\
\hline 9 & 52 & 男 & 他歯科 & 1 & 上兒歯 & 骨内 & $\mathrm{S}$ & $\mathrm{BP}$ & 腫脹 & 上顎洞炎 & 糖尿 & 悪 \\
\hline 10 & 69 & 男 & 他歯科 & 1 & 上全顎 & 骨内 & $\mathrm{B}$ & M & 自発痛 & 顎骨炎神経痛上顎洞炎 & 胃潰瘍 & 悪 \\
\hline 11 & 56 & 男 & 紹介無 & 1 & 上全顎 & 骨膜下 & 0 & - & 自発痛 & 顎骨炎 & 肝炎 & 悪 \\
\hline 12 & 57 & 男 & 紹介無 & 1 & 上全顎 & 骨内 & $\mathrm{SC}$ & IB & 咬合痛 & 顎骨炎 & 肝炎 & 悪 \\
\hline 13 & 47 & 女 & 紹介無 & 2 & 下臼歯 & 骨内 & $\mathrm{B}$ & $\mathrm{B}$ & 咀嚼障害 & 歯槽骨炎·顎関節症 & なし & 良 \\
\hline 14 & 48 & 女 & 他歯科 & 3 & 上前下臼 & 骨内 & SB & $\mathrm{B}$ & 自発痛 & 歯槽骨炎 & なし & 普 \\
\hline 15 & 48 & 女 & 他歯科 & 1 & 下曰歯 & 骨内 & B & M & 咬合痛 & 歯槽骨炎 & なし & 良 \\
\hline 16 & 43 & 女 & 他歯科 & 1 & 上臼歯 & 骨膜下 & $\mathrm{O}$ & - & 腫脹 & 歯槽骨炎·顔面神経痛 & なし & 良 \\
\hline 17 & 61 & 女 & 他歯科 & 1 & 下前歯 & 骨内 & $\mathrm{S}$ & $\mathrm{B}$ & 咀嚼障害 & 歯槽骨炎 & なし & 普 \\
\hline 18 & 50 & 女 & 他歯科 & 3 & 下曰兒上前臼 & 骨内 & $\mathrm{S}$ & $\mathrm{B}$ & 動摇 & 歯槽骨炎 & なし & 普 \\
\hline 19 & 42 & 女 & 他歯科 & 1 & 下臼歯 & 骨内 & $\mathrm{B}$ & M & 腫脹 & 歯槽骨炎 & なし & 悪 \\
\hline 20 & 55 & 男 & 紹介無 & 2 & 下臼歯 & 骨内 & $\mathrm{S}$ & B & 自発痛 & 歯槽骨炎 & なし & 悪 \\
\hline 21 & 56 & 男 & 他歯科 & 1 & 下曰歯 & 骨内 & B & $\mathrm{B}$ & 咬合痛 & 歯槽骨炎 & なし & 普 \\
\hline 22 & 63 & 男 & 他歯科 & 1 & 下曰歯 & 骨内 & $\mathrm{C}$ & $\mathrm{A}$ & 補緅物脱落 & 歯槽骨炎 & 糖尿病 & 普 \\
\hline 23 & 59 & 女 & 埋入歯科 & 2 & 上前歯 & 歯内 & $\mathrm{P}$ & B & 排膿 & 歯槽骨炎 & なし & 普 \\
\hline 24 & 42 & 男 & 埋入歯科 & 1 & 上全顎 & 骨内 & B & $\mathrm{M}$ & 動摇 & 歯槽骨炎 & なし & 普 \\
\hline 25 & 42 & 女 & 他歯科 & 1 & 下曰歯 & 骨内 & B & $\mathrm{B}$ & 排膿 & 歯槽骨炎 & なし & 普 \\
\hline 26 & 46 & 女 & 他科紹介 & 1 & 上前臼歯 & 骨内 & $\mathrm{S}$ & B & 章閉感 & 上顎洞炎 & なし & 良 \\
\hline 27 & 23 & 女 & 他歯科 & 1 & 上臼歯 & 骨内 & $\mathrm{S}$ & B & 動摇 & 歯槽骨炎 · 上顎洞炎 & なし & 普 \\
\hline 28 & 65 & 男 & 他歯科 & 1 & 下曰歯 & 骨内 & B & M & 動摇 & 歯槽骨炎 & 糖尿病 & 悪 \\
\hline 29 & 48 & 女 & 他歯科 & 1 & 下曰歯 & 骨内 & $\mathrm{B}$ & M & 動摇 & 歯槽骨炎 & 胆囊炎 & 普 \\
\hline 30 & 49 & 男 & 本院実施 & 1 & 下曰歯 & 骨内 & $\mathrm{B}$ & $\mathrm{M}$ & 腫脹 & 歯槽骨炎 & なし & 良 \\
\hline 31 & 71 & 女 & 他歯科 & 1 & 上前歯 & 骨内 & $\mathrm{S}$ & $\mathrm{B}$ & 動摇 & 歯槽骨炎 & 高血圧 & 普 \\
\hline 32 & 59 & 女 & 他歯科 & 1 & 下臼柬 & 骨内 & $\mathrm{S}$ & $\mathrm{B}$ & 腫脹 & 歯槽骨炎 · 顎関節症 & 腎疾患 & 普 \\
\hline 33 & 50 & 女 & 他歯科 & 1 & 下臼茵 & 骨内 & $\mathrm{B}$ & M & 自発痛 & 歯槽骨炎 & 貧血 & 普 \\
\hline 34 & 43 & 男 & 他歯科 & 2 & 下臼歯 & 骨内 & SB & $\mathrm{BM}$ & 動摇 & 歯槽骨炎 & なし & 悪 \\
\hline 35 & 60 & 男 & 本院実施 & 1 & 下曰的歯 & 骨内 & B & M & 咬合痛 & 歯槽骨炎 & なし & 普 \\
\hline 36 & 33 & 男 & 他歯科 & 1 & 下臼柬 & 骨内 & $\mathrm{S}$ & B & 腫脹 & 歯槽骨炎 & なし & 悪 \\
\hline
\end{tabular}

[形態] S : スクリュータイプ, B : ブレードタイプ, P : ピンタイプ, C : シリンダータイプ, O : 骨膜下インプラント

[材質] B : バイオセラム, P : バイオセラムポーラス, M : ブレード (メタル), I : ITI, A : アパセラム, S : 形状記憶合金 
表 2 性別・年齢別

\begin{tabular}{l|l|l|r}
\hline \multicolumn{1}{c|}{ 年齢 } & 男 & 女 & \multicolumn{1}{|c}{ 計 $(\%)$} \\
\hline 20 歳代 & 0 & 1 & $1(2.8)$ \\
30 & 1 & 1 & $2(5.6)$ \\
40 & 5 & 9 & $14(38.9)$ \\
50 & 7 & 5 & $12(33.3)$ \\
60 & 4 & 1 & $5(13.9)$ \\
70 & 1 & 1 & $2(5.6)$ \\
\hline 計 (\%) & $18(50)$ & $18(50)$ & $36(100)$ \\
\hline
\end{tabular}

表 3 来院経路

\begin{tabular}{l|r}
\hline \multicolumn{1}{c|}{ 来 院 経 路 } & 症例数 (\%) \\
\hline 埋入処置を施行した歯科から紹介 & $3(8.3)$ \\
埋入処置を施行した以外の歯科から紹介 & $25(69.4)$ \\
直接本院に来院 & $5(13.9)$ \\
耳鼻科からの紹介 & $1(2.8)$ \\
本院にて埋入処置 & $2(5.6)$ \\
\hline \multicolumn{1}{c}{ 計 } & $36(100)$ \\
\hline
\end{tabular}

数, (4)インプラント部位, (5)インプラント形式, (6)イ ンプラント形態，(7)骨内インプラント材質，8主訴， (9)症状, (10)継発症, (11)処置内容, (12)全身疾患の有無, (13) 口腔衛生状態など 18 項目に関して検討した。 なお，口 腔衛生状態については Oral Hygiene Index（以下, OHI）の Debris Index（以下, DI）に準じて評価した。

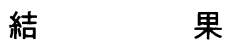

(1) 性別・年齢分布

性別では, 男女とも 18 例で, 性差はなかった。

初診時の年齢では最年少は 23 歳, 最年長は 71 歳で あり, 男性の平均年齢は 54.0 歳で 50 歳代 (38.9\%) を 中心に 40 60歳代 (88.9\%) に多く, 女性の平均年齢 は 48.3 歳で, 40 歳代 (50\%) に多くみられた（表 2 ).

(2) 来院経路

該当患者の埋入処置を施行した歯科医院（以下，埋 入歯科医院）加の紹介 3 例 $(8.3 \%)$, 埋入処置を施 行した以外の歯科医院 (以下, 非埋入歯科医院) から の紹介は 25 例 $(69.4 \%)$, 患者が埋入した歯科医院に 行かずに直接当院に来院したもの 5 例 $(13.9 \%)$, 耳鼻 科からの紹介 1 例 $(2.8 \%)$, 本院にて埋入処置をした もの 2 例 (5.6\%) であった（表 3 ).

(3) インプラント装着数

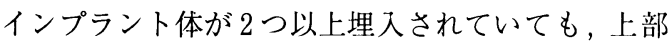

表 41 症例当たりのインプラント装置数

\begin{tabular}{c|c}
\hline 装置数 & 症例数 $(\%)$ \\
\hline 1 & $29(80.6)$ \\
2 & $5(13.9)$ \\
3 & $2(5.6)$ \\
\hline 計 & $36(100)$ \\
\hline
\end{tabular}

表 5 インプラント部位

\begin{tabular}{l|c|c|c|c|c}
\hline & 前歯部 & 前臼歯部 & 䊆部 & 全顎 & 計 (\%) \\
\hline 上顎 & 5 & 4 & 5 & 4 & $18(40)$ \\
下顎 & 1 & 1 & 25 & 0 & $27(60)$ \\
\hline 計 (\%) & $6(13.3)$ & $5(11.1)$ & $30(66.7)$ & $4(8.9)$ & $45(100)$ \\
\hline \multicolumn{5}{c}{ 数値は装置数 }
\end{tabular}

表 6 インプラント形式

\begin{tabular}{l|c|c}
\hline インプラント形式 & 症例数 $(\%)$ & 装置数 $(\%)$ \\
\hline 骨膜下 & $3(8.3)$ & $3(6.7)$ \\
骨内 & $31(86.1)$ & $40(88.9)$ \\
㐘内骨内 & $1(2.7)$ & $1(2.2)$ \\
骨内十芷内骨内 & $1(2.7)$ & $1(2.2)$ \\
\hline \multicolumn{1}{c|}{ 計 } & $36(100)$ & $45(100)$ \\
\hline
\end{tabular}

構造物が連結されているものは 1 装置として数えた. 1 症例当たりのインプラント装置数は，1装置 29 例 $(80.6 \%) ， 2$ 装置 5 例 $(13.9 \%) ， 3$ 装置 2 例 $(5.6 \%)$ で あった (表 4 ).

(4) インプラント部位

36 例（45 装置）をインプラントで補緅される部位に より分類すると, 上顎のみ 14 例 (15 装置), 下顎のみ 19 例 (22 装置), 上下顎 3 例 (8 装置) で, そのうち下 顎臼歯部に適用したものは 20 例（25 装置：55.6\%）で あった（表 5 )。

(5) インプラント形式

骨内インプラントは 31 例 $(86.1 \%), 40$ 装置 $(88.9$ \%) と最も多く，骨膜下インプラントは 3 例 $(8.3 \%)$ ですべて上顎の症例であった（表 6 ).

(6) インプラント形態

インプラント形態はスクリュータイプ単独, ブレー ドタイプ単独がそれぞれ 19 装置 $(42.2 \%)$ あり，2 種 類の異なった形態のインプラントを用いたものが 2 例 あった（表 7 ). 
表 7 インプラント形態

\begin{tabular}{l|r}
\hline \multicolumn{1}{c|}{ インプラント形態 } & 装置数 $(\%)$ \\
\hline スクリュー & $19(42.2)$ \\
ブレード & $19(42.2)$ \\
ブレード+シリンダー & $1(2.2)$ \\
スクリュー+ピン & $1(2.2)$ \\
ピン & $2(4.4)$ \\
骨膜下 (フレーム) & $3(6.7)$ \\
\hline \multicolumn{1}{c}{ 計 $(\%)$} & $45(100)$ \\
\hline
\end{tabular}

表 8 骨内インプラント材質

\begin{tabular}{|c|c|}
\hline 材質 & 装置数（％） \\
\hline バイオセラム (スクリュー) & $17(37.8)$ \\
\hline バイオセラム (板状) & $7(15.6)$ \\
\hline バイオセラム (ポーラス) & $2(4.4)$ \\
\hline バイオセラム (ピン) & $2(4.4)$ \\
\hline ブレード（メタル） & $9(20.0)$ \\
\hline 形状記憶合金 & $1(2.2)$ \\
\hline アパセラム & $1(2.2)$ \\
\hline バイオセラム (スクリュー+ポーラス) & $2(4.4)$ \\
\hline ITI+バイオセラム (スクリュー) & $1(2.2)$ \\
\hline 計 & $42(100)$ \\
\hline
\end{tabular}

表 9 主訴

\begin{tabular}{c|c}
\hline 主 訴 & 症例数 $(\%)$ \\
\hline 自発痛 & $5(13.9)$ \\
咬合痛 & $6(16.7)$ \\
動摇 & $8(22.2)$ \\
腫脹 & $7(19.4)$ \\
排膿 & $4(11.1)$ \\
咀嚼障害 & $2(5.6)$ \\
神経麻痻 & $2(5.6)$ \\
䢙閉感 & $1(2.8)$ \\
補緅物脱落 & $1(2.8)$ \\
\hline
\end{tabular}

(7) 骨内インプラント材質

骨内インプラントを材質で分類するとバイオセラム が最も多く，その中ではスクリュータイプが多かった (表 8 ).

\section{(8) 主訴}

弛緩動摇 8 例 $(22.2 \%)$, 歯肉など周囲組織の腫脹が
表 10 局所症状

\begin{tabular}{l|r}
\hline 局所症状 & 症例数 (\%) \\
\hline 自発痛 & $9(25)$ \\
咬合痛 & $7(19.4)$ \\
動摇 & $23(63.9)$ \\
腫脹 & $9(25)$ \\
排膿 & $12(33.3)$ \\
出血 & $4(11.1)$ \\
著しい骨吸収 & $17(47.2)$ \\
口臭 & $2(5.6)$ \\
顎関節症症状 & $3(8.3)$ \\
肩こり & $1(2.8)$ \\
神経麻痷 & $4(11.1)$ \\
神経痛症状 & $1(2.8)$ \\
鼻・洞炎症状 & $3(8.3)$ \\
補緅物脱落 & $1(2.8)$ \\
\hline
\end{tabular}

重複有り

表 11 継発症

\begin{tabular}{l|c}
\hline \multicolumn{1}{c|}{ 継発症 } & 症例数 (\%) \\
\hline 歯槽骨炎 & $28(77.8)$ \\
顎骨炎 & $3(8.3)$ \\
上顎洞炎 & $5(13.9)$ \\
顎関節症 & $3(8.3)$ \\
下歯槽神経麻痖 & $3(8.3)$ \\
顔面神経麻瘻 & $1(2.8)$ \\
三叉神経痛 & $1(2.8)$ \\
\hline
\end{tabular}

重複有り

7 例 $(19.4 \%)$, 次いで咬合痛が 6 例 $(16.7 \%)$ であった (表 9 ).

(9) 症状

インプラントの病的動摇は 36 例中 23 例 $(63.9 \%)$ にみられ, 次いでインプラント周囲の著しい骨吸収 17 例 $(47.2 \%)$ ，インプラント周囲からの排膿 12 例 (33.3\%) であった. 神経系統に対する不快症状として は, 神経麻盘 4 例（下歯槽神経麻瘏 3 例, 顔面神経麻 痺 1 例), 三叉神経痛様疼痛 1 例, また顎関節症症状が 3 例であった(表 10).

(10) 継発症

継発症を分類すると, 歯槽骨炎は 36 例中 28 例 $(77.8$ \%)にみられ，歯槽骨炎から波及した顎骨炎が 3 例 (8.3\%)，上顎洞炎が 5 例（13.9\%）あった（表 11$).$

(11) 処置内容

インプラント周囲の歯槽骨を削除し, インプラント 
表 12 処置内容

\begin{tabular}{l|c}
\hline 処置内容 & 症例数 $(\%)$ \\
\hline 除去手術 & $33(91.7)$ \\
上顎洞根治手術 & $2(5.6)$ \\
腐骨除去術 & $3(8.3)$ \\
洞穿孔閉鎖術 & $3(8.3)$ \\
顎関節症治療 & $2(5.6)$ \\
その他 & $4(11.1)$ \\
\hline
\end{tabular}

重複有り

表 13 全身疾患

\begin{tabular}{c|c}
\hline 全身疾患名 & 症例数 $(\%)$ \\
\hline 全身疾患有り & $15(41.7)$ \\
[糖尿病 $]$ & {$[4]$} \\
[高血圧症 $]$ & {$[4]$} \\
[腎疾患 $]$ & {$[3]$} \\
[貧血 $]$ & {$[3]$} \\
[肝疾患 $]$ & {$[2]$} \\
[胃潰瘍 $]$ & {$[1]$} \\
[胆のう炎 $]$ & {$[1]$} \\
\hline 全身疾患なし & $21(58.3)$ \\
\hline
\end{tabular}

重複有り

を除去し，周囲の病的肉芽組織を掻爬した症例は 33 例 $(91.7 \%)$ ，上顎洞根治手術 2 例 $(5.6 \%)$ ，インプラン 卜周囲の腐骨を大きく削除した症例は 3 例 $(8.3 \%)$, 上顎洞瘦孔閉鎖術 3 例 $(8.3 \%)$, 顎関節症治療 2 例 (5.6\%)，その他 4 例（11.1\%）であった（表 12).

麻酔法について，観血的処置を行った 31 例中，全身 麻酔が 2 例 (6.5\%), 局所麻酔あるいは局所麻酔と静 脈鎮静法を併用した症例は 29 例 $(93.5 \%)$ であった。

入院にて処置した症例は 4 例 $(11.1 \%)$ で，他の 32 症例 $(88.9 \%)$ は外来通院にて処置を行った.

(12) 全身疾患の有無

全身疾患を有している症例は 15 例 (41.7\%) であり， その内訳は糖尿病 4 例, 高血圧症 3 例, 腎疾患 3 例, 貧 血3例などであった（表 13）.

\section{(13) 口腔衛生状態}

口腔衛生状態は OHI の DI に基づいて評価した. DI の評価点数 $0 \sim 2$ 点未満を口腔衛生状態（良），2４ 点未満を口腔衛生状態 (普通), 4 ～6 点を口腔衛生状 態 (悪)とした.

（良）は6例 $(16.7 \%)$, (普通)は 18 例 $(50 \%)$ ，（悪） は 12 例（33.3\%）であった（表 14）。
表 14 口腔衛生状態

\begin{tabular}{c|c}
\hline 口腔衛生状態 & 症例数 (\%) \\
\hline 良 & $6(16.7)$ \\
普通 & $18(50)$ \\
悪 & $12(33.3)$ \\
\hline 計 & $36(100)$ \\
\hline
\end{tabular}

表 15 口腔衛生指導の有無

\begin{tabular}{c|c}
\hline 口腔衛生指導 & 症例数 $(\%)$ \\
\hline 有 & $12(33.3)$ \\
[バス法 $]$ & {$[4]$} \\
[ローリング法 $]$ & {$[2]$} \\
{$[$ 不明・その他 $]$} & {$[6]$} \\
\hline なし & $24(66.7)$ \\
\hline
\end{tabular}

(14) 口腔衛生指導の有無および指導内容

インプラント治療に当たり口腔衛生指導を受けたは 12 例 (33.3\%), 受けていないは 24 例 $(66.7 \%)$ であっ た。指導内容はブラッシング法が主で，バス法 4 例, ローリング法 2 例, 口腔衛生指導を受けたがどのよう な方法か忘れた・歯を磨くように言われたが実際の指 導は受けていないなどが 6 例であった（表 15).

(15) インプラント埋入処置を受けた年齢

インプラント処置を受けた年齢は 10 歳代は 2 例 (5.6\%), 20 歳代は 1 例 $(2.8 \%), 30$ 歳代は 12 例（33.3 $\%), 40$ 歳代は 8 例 $(22.2 \%), 50$ 歳代は 10 例 $(27.8 \%)$, 60 歳代は 3 例 $(8.3 \%)$ で, 平均年齢は 44.4 歳であった。 男女別では男性は 40～50 歳代に多く，11 例（61.1\%） を占めていた. 女性は 30 歳代が最も多く 10 例（55.5 \%)であった（表 16).

(16) 埋入処置から症状が出現するまでの期間

手術直後から何らかの不快症状がインプラントを除 去するまで持続した症例は 15 例 $(41.7 \%) ， 6$ か月～1 年未満に症状が出現した症例は 1 例 $(2.8 \%), 1 〜 5$ 年末满は 8 例 $(22.2 \%), 5 \sim 10$ 年末満は 5 例 $(13.9 \%)$, 10 年以上は 7 例 $(19.4 \%)$ であり, その平均は 4.2 年で あった。なお，性差は見られなかった（表17，図1）。

(17) 埋入処置から除去手術までの期間

埋入手術中に症状が出現したために埋入を中止して インプラントを除去したものは 1 例 $(2.8 \%)$ ，埋入手 術から 6 か月未満に除去手術を行った症例は 1 例 $(2.8$ $\%), 1 \sim 5$ 年未満の症例は 13 例 $(36.1 \%), 5 \sim 10$ 年 末満の症例は 10 例 $(27.8 \%), 10$ 年以上経ってから除 去手術を行った症例は 9 例 $(25.0 \%)$, 症状が消失ある 
表 16 インプラント処置した年齢

\begin{tabular}{l|l|r|r}
\hline \multicolumn{1}{c|}{ 年齢 } & 男 & 女 & 計 $(\%)$ \\
\hline 10 歳代 & 1 & 1 & $2(5.6)$ \\
20 & 1 & 0 & $1(2.8)$ \\
30 & 2 & 10 & $12(33.3)$ \\
40 & 5 & 3 & $8(22.2)$ \\
50 & 6 & 4 & $10(27.8)$ \\
60 & 3 & 0 & $3(8.3)$ \\
70 & 0 & 0 & $0(0)$ \\
\hline 計 & 18 & 18 & $36(100)$ \\
\hline
\end{tabular}

表 17 埋入処置から症状が出現するまでの期間

\begin{tabular}{|c|c|c|c|}
\hline 期 間 & 男 & 女 & 計 (\%) \\
\hline 手術直後から & 8 & 7 & $15(41.7)$ \\
\hline 6 か月未満 & 0 & 0 & $0(0)$ \\
\hline 6 か月 1 年未満 & 1 & 0 & $1(2.8)$ \\
\hline $1 \sim 5$ 年末満 & 4 & 4 & $8(22.2)$ \\
\hline $5 \sim 10$ 年未満 & 1 & 4 & $5(13.9)$ \\
\hline 10 年以上 & 4 & 3 & $7(19.4)$ \\
\hline 計 & 18 & 18 & $36(100)$ \\
\hline
\end{tabular}

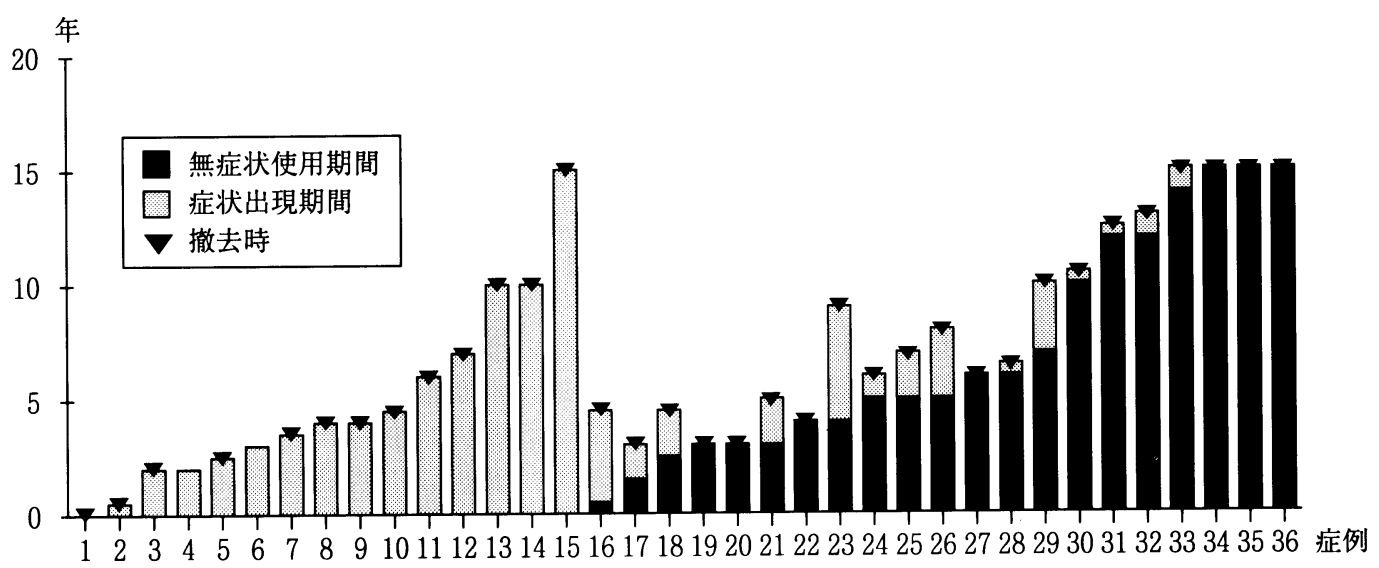

図 1 インプラント使用期間と撤去時期

いは軽減したために経過観察中の症例は 2 例（5.5\%） で, その平均は 6.8 年であった（表 18, 図 1 ).

(18) 症状が出現してから除去手術までの期間

症状出現してからすぐに除去手術を行った症例は 8 例 $(22.2 \%) ， 6$ か月未満に除去した症例は 2 例 $(5.6$ $\%), 6$ か月〜 1 年未満に除去した症例は 2 例 $(5.6 \%)$ ，
表 18 埋入処置から除去手術までの期間

\begin{tabular}{|c|c|c|c|}
\hline 期 間 & 男 & 女 & 計 (\%) \\
\hline 手術中 & 0 & 1 & $1(2.8)$ \\
\hline 6 か月未満 & 0 & 1 & $1(2.8)$ \\
\hline 6 か月～1 年未満 & 0 & 0 & $0\left(\begin{array}{l}0\end{array}\right)$ \\
\hline $1 \sim 5$ 年末満 & 7 & 6 & $13(36.1)$ \\
\hline $5 \sim 10$ 年未満 & 6 & 4 & $10(27.8)$ \\
\hline 10 年以上 & 4 & 5 & $9(25.0)$ \\
\hline 経過観察中 & 1 & 1 & $2(5.5)$ \\
\hline $\begin{array}{c}\text { 計 } \\
\end{array}$ & 18 & 18 & $36(100)$ \\
\hline
\end{tabular}

表 19 症状が出現してから除去手術までの期間

\begin{tabular}{|c|c|c|c|}
\hline 期 間 & 男 & 女 & 計 (\%) \\
\hline 直後 & 5 & 3 & $8(22.2)$ \\
\hline 6 か月未満 & 1 & 1 & $2(5.6)$ \\
\hline 6 か月～1 年未満 & 1 & 1 & $2(5.6)$ \\
\hline $1 \sim 5$ 年末満 & 8 & 8 & $16(44.4)$ \\
\hline $5 \sim 10$ 年未満 & 2 & 2 & $4(11.1)$ \\
\hline 10 年以上 & 0 & 2 & $2(5.6)$ \\
\hline 経過観察中 & 1 & 1 & $2(5.6)$ \\
\hline 計 & 18 & 18 & $36(100)$ \\
\hline
\end{tabular}


考

察

対象の 36 症例に性差はなかったが, 初診時の年齢 では男性の平均年齢は女性より約 5 歳高かった。これ は女性のほうが早く歯を衰失する ${ }^{20)}$ ために, 早期にイ ンプラント処置を受けること, また一般にいわれてい るように骨量, 骨質とも男性より劣り, 長持ちしない ことに起因するものと思われる。

来院経路としては直接来院 5 例, 非埋入歯科医院か らの紹介 25 例, 耳鼻科からの紹介 1 例であり, 合わせ て 31 例 $(86.1 \%)$ が埋入処置を実施した医療機関を訪 れていない. 当院では埋入した医療施設の責任や医療 の向上のためにも必ず埋入した医療機関を受診するよ うに患者に指導しているが，遠方から転居してきた場 合や実施した医療機関が閉院した数例を除くとほとん どの症例が実施医療機関には二度と行きたくないと訴 えたため, 結果として当院で処置した. 患者の訴えを 聞くとインプラント治療および実施医療機関に対する 不信感ならびに不満が浮彫りにされた。これは当該医 療機関におけるインプラント治療に対する説明やイン フォームドコンセントの不足あるいは欠如に起因して いるものと考えられた. 榎本 ${ }^{1}$ ) はインプラントによる 患者との間のトラブルのうち金銭的解決は $2.3 \%$, 訴 訟に至ったものが僅か $1.5 \%$ であり，一般に言われて いる程多くはないと述べているが, 本報告の症例の中 には不満を訴えるものが数多くあり，いわゆるトラブ ルが表面化していないものと推測された。

埋入歯科医院からの紹介 3 例 $(8.3 \%)$ は, 下歯槽神 経麻痺 1 例, 歯槽骨炎 2 例であり, 自医院での処置が 不可能なために紹介してきた症例であった．耳鼻科か らの紹介は片頭痛, 鼻閉感, 後鼻漏など上顎洞炎の症 状を呈していたため耳鼻科を訪れた症例である。イン プラント治療の普及にしたがい経過不良インプラント 患者が歯科医院を訪れるケースがみられるが，十分な 説明を行い, 慎重に対処する必要があり，また，大学 病院などの医療機関に紹介することも一法である。

天然歯と連結した装置か単独植立かについては骨膜 下インプラントの 2 例を除きすべて天然歯と連結して いた. インプラントと天然歯との連結の良否が論議さ れているが, 今回使用されていたすべての骨内インプ ラントは適応が天然歯と連結するのが基本となってい たためであり, 天然歯との連結が除去を早めることに なったかは疑問の残るところである.

一般にインプラントの適用は無歯顎症例より天然歯 の支台歯だけではブリッジが不可能な局部欠損症例に 多いとされている.そのためインプラントを上顎ある いは下顎のいずれか一方あるいは片顎に用いることが 多い. 今回の報告でも全体の $92 \%$ 上下顎いずれか一 顎に用いられていた。一顎全部をインプラントにて修
復していた症例は 4 例あったが, すべて上顎の症例で あった。また，無歯顎症例は 1 例で，上顎に骨膜下イ ンプラントが装着されていた。

インプラントと義歯を併用している症例はなかった。 また欠損部位があっても補経をせずに放置している症 例が 8 例あった.これは義歯を嫌って欠損状態のまま で我慢しているためであった。

インプラント形式では, 骨内インプラントが 31 例, 40 装置と最も多かったが, 現在の主流が骨内インプラ ントであり，絶対数が多いためと考えられる，骨膜下 インプラントはすべて上顎の症例で, 骨内インプラン トでは対忍できない上顎洞底が低い症例であった。

インプラントの形態をみるとスクリュータイプ単独, ブレードタイプ単独がそれぞれ 19 装置あり，2 種類 の異なったタイプのインプラントを用いた症例が 2 例 あった.ひとつのインプラント形態にこだわらず，骨 量, 骨質, 適用部位に合わせて最適なインプラント材 を使用すべきである。

骨内インプラントにはバイオイナートな材料とバイ オアクティブな材料があり，現在ではそれぞれ素材の 特性を生かして使用されていると思われるが，今回の 結果ではバイオイナートな材料であるバイオセラム単 結晶がもっとも多く $61.9 \%$ であった。 これはインプラ ント治療が臨床で広く㐫用され始めた昭和 50 年代 60 年代に多く使用され，インプラント導入の先駆者で あり, 講習会が頻回に行われ，器材が入手しやすいこ ともあり，まず手掛けることの多い夕イプであったこ と，また現在までにもっとも多く埋入されたこと，さ らに長期間使用の限界に来ているためと考えられる。 ブレードタイプは Linkow 旧型ブレードインプラン トでバイオセラム同様, 昭和 50 ～60 年代に多く使用 されていたが, この両者とも現在では使用している医 療機関は少なくなってきていると思われる.現在使用 が増加しているのはITI-Bonefit, ブローネマルク， IMZ インプラント, スミシコン, その他のため, 今後 は除去するインプラントの種類も変貌するものと思う.

初診時の主訴はインプラントの動摇 8 例, 歯肉等周 囲組織の腫脹が 7 例，次いで咬合痛が 6 例であった。 西嶋ら ${ }^{9)}$ は撤去した 5 症例のうち 3 例が有痛性の腫 脹と報告しており，本報告も同様に神経麻瘏，鼻閉感 以外は主に「痛くて咬めない」など，咀嚼時に生じる 症状を主訴とする症例が多かった。

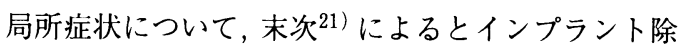
去の原因となった主徴候は著しい骨吸収で $31.1 \%$ にあ たっている．本報告でも著しい骨吸収は 17 例 $(47.2$ \%）にみられ，程度の差はあれほとんどの症例に骨吸 収が認められた. 特に,ブレードタイプ（メタル）は 他の材質のものに比べ骨吸収が著しかった。これは一 度起こった骨吸収がブレードの沈下と相俟って拡大し ていくものと思われる. バイオセラムは骨吸収は僅か 
であるが，連結された天然歯に破折や動摇をきたす症 例が多かった。こればイオセラムが咬合力を十分に 支えきれないために天然㐘に影響を及ほしたためと思 う。アパセラムは 1 例であったが全く骨の吸収は認め られず, かえってインプラント周囲の骨は硬化してお り,インプラントの材質・形態による骨吸収の差異と 考えられた。

末次 ${ }^{21)}$ によると動摇は $18.9 \%$ であるが, 本報告では 23 例 $(63.9 \%)$ にみられた。然歯との連結を基本に しているバイオセラムは天然歯と双方に動摇を生じる ことが多く, バイオセラムが咬合圧を十分に負担しき れていないためか，設計に問題があったためである.

排膿は 12 例にみられ，骨吸収が著明な症例に多かつ た。 また, 出血は 4 例で, いずれも排膿を伴う怔例で ブラッシング時, 咬合時, あるいは安静時にも舌圧な どにより動摇しているインプラント周囲の歯肉から出 血が認められたが, いずれも自然止血する程度であっ た。

咬合時に疼痛を伴うものは 16 例であり，うち 9 例 は自発痛を伴っていた。これらは歯周病の症状に似て いるが, 連結している天然歯と比べると明らかにイン プラント部の病状が進んでいた。

片頭痛, 眼窩下部のび慢性の腫脹, 後鼻漏, $\mathrm{X}$ 線写 真における上顎洞の不透過性の元進など慢性上顎洞炎 の症状や鼻閉感を訴えた症例は上顎大臼歯部に埋入さ れた 8 例中 5 例にみられた. 森川ら ${ }^{6)}$, 岡野ら ${ }^{14)}$ は骨 膜下インプラントにより，山田 ${ }^{15)}$ は骨内インプラント， 歯内骨内インプラントにより，亀谷ら ${ }^{3)}$, 中野10) ら, 岩田ら ${ }^{16)}$ は骨内インプラントにより上顎洞炎を継発 した症例を報告してる。上顎洞内への穿孔・植立，イ ンプラントの沈下や歯槽骨炎から上顎洞炎への波及な ど，上顎症例でもっとも考虑しなければならないこと は上顎洞との位置関係であることがわかる。

神経麻痺に関して森川ら6) は骨膜下インプラント の沈下により生じた眼窩下神経麻痺を, 西村ら ${ }^{12)}$, 岩 崎ら ${ }^{11)}$ は骨内インプラントの沈下により生じた下歯 槽神経麻瘏を報告している. 末次 ${ }^{21)}$ はインプラント治 療後 $65.8 \%$ が 1 年以内に, すべての症例が 5 年以内に みられたと報告している. 本報告では下歯槽神経麻痺 3 例, 顔面神経麻瘏 1 例の計 4 例にみられた。歯槽神 経麻瘏の 3 例はすべて術直後から発症しており, 術中 の下歯槽神経の損傷によるものである。

顔面神経麻㾇は骨膜下インプラントの術後約 6 か月 後に発症した症例で，麻㾝の原因は確定できないが， 症状と経過からインプラント周囲歯肉の炎症と動摇か ら歯槽骨の吸収をきたし, 沈下したインプラントが顔 面神経を刺激したものと思われる.すなわち神経麻痺 はインプラントが口腔内で安定したあとには生じにく く, 術中, 術直後に生じることがわかる.

開口障害, 関節雑音を呈する顎関節症の症状は 3 例
にみられた.いずれも術前, 術直後には顎関節症の症 状がみられず，インプラントの沈下による咬合高径の 減少が主原因と思われる。

処置内容について, 36 例中 33 例はインプラントを 除去し, 周囲の病的肉芽組織を搔爬した。インプラン 卜周囲に X 線透過像がみられるスクリュータイプは ねじを逆回しにすることにより容易に除去することが できた。しかしブレードタイプはショルダー部の骨を 削除しなければならず, 特にバイオセラム単結晶のプ レートタイプは骨削・除去時に破折しやすいので, 広 範囲に骨に侵襲を与えてしまう。ブレード（メタル） と骨膜下インプラント, 特に骨膜下インプラントは脚 部に線維性の㓔痕組織が周囲の歯肉や骨膜と絡み付き, 除去が困難であった。歯槽骨炎から波及した顎骨炎は 3例あり，硬化性の骨炎を併発していたため周囲の健 康な骨が露出するまで, 硬化した骨を除去した．角 ${ }^{17)}$ は下顎骨骨髄炎に進展した骨内インプラントを報告し ているが本報告例の中にはなかった。

上顎洞炎を継発した 5 例のうち 3 例はインプラント を除去し，抗生剂の投与により消炎した。しかし，上 顎洞への侵襲の大きな 2 例は上顎洞根治手術ならびに 洞瘦孔閉鎖手術を行った。これらは骨吸収が広範囲で, 不良肉芽のため歯槽骨周囲の粘膜の欠損が著しく，し かも㓔痕が強いため瘦孔閉鎖に苦労した症例である.

インプラント除去手術を行っていない 4 例のうち, 2 例はインプラントを除去せずに改善し, 他の 2 例は 埋入手術時に下歯槽神経に損傷を与えたものである. 改善した症例のうちの 1 例（症例 No 4) は歯肉炎と 咬合痛を訴えたバイオセラム単結晶プレートタイプの 症例で, ブラッシングなどの口腔衛生指導により症状 が消失した。もう 1 例（症例 No32）はインプラントの 骨植は良好だが上部構造物が脱離・破損した症例であ り，再度上部構造物を作製した。埋入手術時に下歯槽 神経に損傷を与えた症例のうち 1 例はドリリング時に 損傷したことに気づいたため埋入手術を中止し，当院 に紹介来院した. 処置としてはステロイド剤, ビタミ ン剂の投与にあわせソフトレーザーの照射を行い, 症 状の改善が見られた。他の 1 例は術後に神経の損傷に 気づいたが, 知覚鈍麻を僅かに感じる以外症状がなく， 患者が除去に応じないために薬物投与し, 現在は経過 観察中である。

麻酔法について，観血処置をおこなった 31 例中全 身麻酔を用いたのは 2 症例で，いずれも上顎の症例で， 顎骨への侵襲範囲が広く，処置に時間がかかるためで あった。

入院にて処置した症例は 4 例で, 全身麻酔あるいは 局所麻酔と静脈鎮静法を併用した症例であった。局所 麻酔か全身麻酔か, 入院処置か外来処置かの選択基準 は一般の外科処置に準じて良いが，上顎全顎にわたり， しかも上顎洞に波及している症例は全身麻酔・入院処 
置を選択すべきである

全身疾患を有している症例は 15 例であった，厚生 省の報告 ${ }^{20)} に$ 比べ多いわけではないが, 感染症を引き 起こしやすい糖尿病, 貧血, 腎不全で人工透析を受け ている患者, 副腎皮質のステロイド剤投与中の患者が 含まれていた. 上記の患者のすべてがインプラント治 療の禁忌ではないが, 長期間の口腔内安定性に疑問が あるため, 処置には十分な配慮が必要である。

口腔衛生状態をDIに準じて評価した結果，(良) は

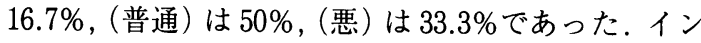
プラントは天然歯に比べ歯垢が付着しやすい傾向があ るため, 口腔衛生状態が悪いと歯頸部から感染しやす く，一度感染すると進行が早い特徴を有しているにも かかわらず (普通)（悪）を合わせると $88.3 \%$ が腔衛 生状態が良好でないことになる。これは単に患者だけ でなく，口腔内を管理・指導すべき術者側にも責任が ある.表 14 に示す通り，インプラント治療に際し，口 腔衛生指導を受けた症例は $33.3 \%$ に過ぎず，しかもそ の内容は一般的な刷掃指導のみであり, インプラント の管理に適した口腔衛生指導を受けた症例はなかった。 インプラント治療の最前線で活躍している日本インプ ラント学会の評議員を対象としたアンケート ${ }^{21)}$ の中 で, 患者に与える注意事項として最も大切なのは「ブ ラッシング指導」であると答えたのが $96.3 \%$ と圧倒的 に高い率を示しており，インプラント頸部がインプラ ントの存否に関わる最重要ポイントであることが認識 されていることを示している.すなわち，口腔衛生指 導はインプラントの寿命を大きく左右する欠くことの 出来ない事項であるにもかかわらず, 十分な指導を行っ ていない傾向が伺われた.

インプラントを埋入してから症状が出現し，除去手 術にいたるまでの表 17〜表 19 をまとめたのが図 1 で ある.インプラント装着後特別な症状がなく経過した 期間と，何らかの症状があっても使用していた期間 (病脳期間), インプラントを除去した時点をそれぞれ 示したものである.手術直後から症状があったもの (以下, 有症状使用群) は 15 例で, そのうち 1 例（症例 4 ) は入念なブラッシングなど口腔衛生指導を行った ところ 2 年間続いていた咬合痛などの症状の改善が見 られた. 埋入直後から何らかの症状が出現したにもか かわらずすぐに除去したものは術中に下口唇麻瘴を起 こした僅か 1 例（症例 1 ）だけで, 多くの症例は症状 が出現しても直ぐには除去せず, 埋入から除去までの 期間は最長は 15 年, 平均は 5.1 年であった。一方埋入 処置後無症状で使用できた期間があるもの（以下，無 症状使用群）は 21 例で, 無症状で使用していた期間は 最短半年, 最長 15 年で平均 7.1 年であった。無症状使 用群が症状出現して使用していた期間は最短で症状出 現直後, 最長でも 5 年, 平均 1.3 年で, 有症状使用群の 平均 5.1 年に比べてかなり短いことがわかる.すなわ
ち, 図 1 のように $3 \sim 7$ 年間使用していた症例が半数 有り, 有症状使用群であっても無症状使用群であって もすぐには除去せず, 数年間は症状が消失するのを待っ ていることが伺える.このように埋入直後から症状が 出現したにもかかわらず, すぐに除去しない理由とし ては, 術者も患者もせっかく装着したのに，すぐには 除去したくないと思い,なんらかのリカバリー処置を 試みたためであろう。

有症状使用群と無症状使用群を比較してみると, 性 別では男性は双方とも差が認められないが, 女性は有 症状使用群 6 例, 無症状使用群 12 例で無症状使用群 が 66.7\%を占めていた. 部位では上顎は双方とも差が 認められないが, 下顎では無症状使用群が 15 例 $(68.2$ \%)で, 上顎に比べて症状が出現しにくかった。全身 疾患の有無について, 有症状使用群は 15 例中 9 例（60 $\%)$, 無症状使用群は 21 例中 6 例 $(28.6 \%)$ で, 有病者 はインプラントが適応しにくいことがわかる.

インプラント治療の成功, 経過不良とはいったいな んだろうか？インプラントの成功基準については NIH ハーバード会議 (Schnitman \& Schulman 1979 ${ }^{22)}$, Albrektsson, Zarb, Worthington \& Eriksson らの提案 ${ }^{23)}$, さらに日本口腔インプラント 学会評議員を対象とした調査による客観的基準21) な どがある。これらの基準をみると，動摇がないこと， 解剖学的損傷がないこと, 咬合痛, 打診痛, 自発痛な ど疼痛がないこと，歯肉炎など感染がないこと，X 線 学的に観察されるX 線透過像がインプラント周囲に 見られないこと，さらに垂直的骨吸収がないこと，咬 合関係が正しく保たれていることなどが成功の条件で ある.すなわち,これらすべての基準を満たさないも のは経過不良症例と判定する。

本報告例はすべての症例において上記の基準を満た しておらず, 多くの症例は数項目にわたり満たしてい なかった。

一度埋入したインプラントは一生もつとは限らず， いつかは除去することを考えなければならない．長期 間の使用後に除去するならともかく，埋入直後から不 快症状があり，それが消えることもなく，しかも何年 も苦しんだあげく除去するような症例があることはイ ンプラント治療に携わるものにとって誠に残念である. このようなことを防ぐには, 多くの人が報告している ように以下のような基本を守ることである.すなわち, 適応症を厳選する。基本術式を守る，術前・術中の消 毒, 術後感染の予防につとめる. 適正な咬合関係を得 る. 適切な口腔衛生指導を行う. 定期検診をおこない, 万が一経過不良の症状が生じたらただちにリカバリー 処置をおこなう。リカバリー処置が不可能なら骨の保 護のために早めに除去する.インフォームドコンセン トを確立する。 
結 語

1989 年から 1993 年までの 5 年間に当院に来院した 経過不良インプラント症例 36 例について，18 項目に 瓦って臨床的に検討し, 以下の結果を得た。

1. 経過不良インプラントが周囲の骨や隣在歯にお よほす影響は, インプラントの材質や形態の種類によ り異なった。

2. 継発症は歯槽骨炎がもっとも多く, 顎骨炎, 上 顎洞炎, 下歯槽神経麻痺，顔面神経麻盘，顎関節症な ど多岐に瓦っていた。

3. 全身疾患を有している症例は, 早期に症状が出 現する傾向があった。

4. 口腔衛生状態の悪い症例は, 早期に症状が出現 する傾向があった.

5. 埋入直後から何らかの症状があり，その症状が 除去まで持続した症例は, 症状が発現してもすぐには 除去しない場合が多かった。

6. 異常な症状がなく使用できた期間がある症例は, 埋入直後から症状があった症例に比べ, 症状出現後短 期間で撤去する傾向があった。

\section{引用 文 献}

1）榎本昭二 : 歯科インプラントの現状に関する調 査研究. 歯医学誌 13: 53-75 1994.

2）松本常男: 骨膜下インプラントおよび骨内イン プラントの症例におけるトラブルの対処につい ての考察.インプラント誌 5:58-631984.

3）亀谷明秀, 柘植一刀, 他 : 鼻腔への挺出が認め られた歯内骨内インプラントの 1 例と失敗例の 文献的考察. インプラント誌 $8: 46-491987$.

4) 山内六男, 中里剛一郎, 他：インプラント摘出 後の補緅例と摘出インプラントの細菌学的検索 (抄). インプラント誌 $2: 300-3011989$.

5) 恩田眞司, 山内六男, 他 : バイオセラムインプ ラント埋入後に不快症状を惹起した症例の再埋 入による補緅例（抄）.インプラント誌 $2: 301$ 1989.

6）森川雅之, 西嶋克巳, 他：インプラントにより 知覚異常ならびに上顎洞炎を生じた 1 例. 口腔 インプラント誌 3:235-240 1990 .

7）田辺晴康, 杉崎正志, 他：上顎洞炎を併発した インプラント施行患者 (抄). 日ロ腔インプラン 卜誌 $3: 2851990$.

8）陶山ケイ子：インプラント埋入後に起きたオト ガイ部麻㾝における考察 (抄). 日ロ腔インプラ ント誌 $3: 2951990$.
9）西嶋 寛, 吉井 剛, 他：インプラント撤去を 行った予後不良 5 例の臨床的検討. 日口腔イン プラント誌 4: 7 -13 1991.

10）中野喜右人, 山川 治, 他：上顎洞内に穿孔を きたした全顎骨内インプラントの撤去症例 (抄). 日ロ腔インプラント誌 $4: 113-1141991$.

11）岩崎 均, 岩間 豊, 他: 外科的手術後の下唇, オトガイ部の知覚麻㾇について (抄). 日口腔イ ンプラント誌 $4: 1141991$.

12）西村敏治, 大野正光, 他 : インプラント体の沈 下が原因と考えられる下唇麻㾇をきたした一例 (抄). 日ロ腔インプラント誌 $4: 1451991$.

13）尾関雅彦, 金 鮮妃, 他：予後不良インプラン 卜の治療法に関する研究 (第 1 報), 病理学的, 口腔外科的ならびに歯科補緅学的検討. 日口腔 インプラント誌 $4: 139-1591991$.

14）岡野篤夫, 尾崎守男, 他 : 上顎洞炎を併発した 骨膜下インプラントの 2 症例 (抄). 日ロ腔イン プラント誌 $5:$ 122-123 1992.

15）山田耕治, 梶 隆一, 他: インプラントによっ て上顎洞炎を継発したと思われた 1 症例（抄）. 日ロ腔インプラント誌 $5: 135-1361992$.

16）岩田雅裕, 西嶋克巳, 他：インプラントにより 上顎洞炎を発症した 1 例 (抄). 日口腔インプラ ント誌 $5: 159-1601992$.

17）角 保德, 岡崎恭宏, 他：インプラント手術後 再燃により下顎骨骨䯣炎に進展した一例。日ロ 腔インプラント誌 6:111-116 1993.

18）加藤仁夫, 武田 譲, 他 : 仮性三叉神経痛と上 顎洞炎を惹起した骨内インプラント.日口腔イ ンプラント誌 $6:$ 136-141 1993.

19）眯田利孝: インプラントの歴史的考察. 歯科ジャー ナル 35: 401-408 1992.

20）厚生省健康政策局歯科衛生課編：昭和 62 年歯 科疾患実態調査報告. 医歯薬出版, 東京, 1987 年.

21）末次恒夫, 古谷野潔, 他 : ロ腔インプラント臨 床の現状調查. 日ロ腔インプラント誌 $6: 142$ 1571993.

22) Schnitman, P.A., Schulman, L.B.: Dental implants, benifits and risk, an NIHHarvard consensus development conference, U.S. Dept of Health and Human Survices: 1 -351 1979.

23) Albrektsson, T., Zarb, G., et al: The long term efficacy of currently used dental implants, A review and proposed criteria of success. Int, Oral and Maxillo implant 1: 11-25 1986 . 